\title{
Model of Independency Mother in Caring for Preterm Infant based on Experiential Learning Care (ELC)
}

\author{
Noer Saudah $^{1}$, Nursalam $^{2}$, Meriana $^{3}$, Agus Sulistyono $^{4}$ \\ ${ }^{1}$ Departement Maternity of Nursing, STIKES Bina Sehat PPNI, Indonesia \\ ${ }^{2}$ Departement of Management Nursing, Airlangga University, Indonesia \\ ${ }^{3}$ Departement of Nutrition Public Health, Airlangga University, Indonesia \\ ${ }^{4}$ Departement of Feto-Maternal Medicine, Airlangga University, Indonesia
}

\section{Article Info}

Article history:

Received Oct 13, 2015

Revised Nov 12, 2015

Accepted Nov 28, 2015

\section{Keyword:}

First independent

Fourth goal attainment

Second preterm infant

Third experiential learning care

\begin{abstract}
The role of parents has done less during the preterm infant care in hospitals caused dependence in caring for the baby. The objective of the research was to development a model of independence of the mother in the care of preterm infants with experiential learning approach based theory of goal attainment. Research's design used analytic correlational in stage 1 and stage 2 used quasy experimental. The population used all mothers with preterm infants treated in perinatal dr. Wahidin Sudiro Husodo Mojokerto and Prof. Dr Soekandar Mojokerto Hospital with sample size was 28 samples respectively in the treatment group and the control group.Variables used knowledge, decision, action, interaction, experiential learning, and mother independence.The instrumen used questionnaire and checklist. The sample was selected by consecutive sampling method. In the treatment group was given ELC module and the control group was given treatment by leaflets. Technical data analysts used Partial Linear Square (PLS) and independent ttest. New finding of research is interaction with the approach of Experiential Learning Care (ELC) through methods role play a stronger in improving the independence than interaction direct to independence.
\end{abstract}

Copyright ( 2015 Institute of Advanced Engineering and Science. All rights reserved.

\section{Corresponding Author:}

Noer Saudah,

Departement of Public Health,

Airlangga University.

Email: saudah_noer@yahoo.co.id

\section{INTRODUCTION}

Preterm birth was the leading cause of death in newborns. Babies who died of preterm accounted for $36.5 \%$ of infant deaths in 2005[1]. In Indonesia the Infant Mortality Rate (IMR) was still high. Result of Indonesia Demography and Health Survey (IDHS) in 2012, IMR was 32/1000 live births. In Indonesia, the causes of perinatal mortality was 0-7 days due to preterm in the amount of $32.3 \%$ was ranked second after respiratory disorder, while the perinatal $7-28$ days as much as $12.8 \%$ [2].

Preliminary studies conducted by researchers at the Regional General Hospital (Hospital) Dr. Wahidin Sudiro Husodo Mojokerto showed the incidence of preterm birth was high. Data obtained from medical records from 2009 to 2013 showed the incidence of preterm birth was still above 12\%. During hospitalization, the participation of mothers of preterm infants in the care of infants was still limited to breastfeed and holds the baby. The role of poor parents during preterm infant care in hospitals would cause independency in caring for the baby after discharge from the hospital [3].

Baby care in the NICU was a source of stress for parents. Stress includes concern for the survival of infants and the potential effect on his development [4]. Parents tend to see themselves as secondary caregivers for babies, whereas the nurse in the NICU was seen as the primary caregivers [5]. Experience the 
stress of parents of preterm infants can delay the achievement of the role of parents [6] and may have long term effects on parent-infant interaction and child developmen [7].

The important task of nurses is to design and assess interventions that focus on the mother and baby, including stress and parental competence [6]. During this intervention has done a nurse, is less successful in increasing the independence of mothers in the care of preterm infants. Researchers are interested in increasing the independence of mothers caring for preterm infants with optimal engagement in hospital care. One cornerstone of thinking and help deliver the baby preterm mothers prepare to be able to care for her baby with optimum is to use the King's nursing model.

King's theory is based on the achievement of objectives and a precise when applied to interactions between mothers of preterm infants with a nurse. Many research and studies that support the theory King centered on the technical aspects of client care and nursing care systems. This theory is quite adequate, logical and sequential occurrence of a nursing. The concept put forward is quite clear and simple (Fawcett, 2006) [8]. However, according to investigators still was abstract theory on transactional stage between the nurse and the client so it can not immediately be applied in concrete. King does not explain the causal relationship between knowledge, decisions, actions and reactions that seem to stand on its own four that are not interrelated. Researchers found King's theory would be appropriate if it is integrated with the Experiential Learning. Experiential Learning methods required as the operational form of transaction between nurses and parents of preterm infants.

Doni (2009) showed the success of $78 \%$ of students used learning experiential [9]. Experiential learning methods to accommodate the social situation, creativity and intellectual mother so as to provide insight into the knowledge of the needs and care of preterm infants and provide a real experience that will build skills or preterm infant care practices. Increasing the independence of mothers in taking care of the preterm infant would help lower the infant mortality rate (IMR). Nursing care through Experiential learning approach with Model-based Theory of Goal Attainment use the experience as a catalyst can help mothers in developing the capacity and ability to care for preterm babies through learning by doing.

The purpose of this study is to construct a model of independence mother in caring for preterm infants through experiential approach Learning Care (ELC) based Theory of Goal Attainment.

\section{RESEARCH METHOD}

This research was an analytical study conducted correlational includes 2 stages. The first stage used a design explanation. Explanation design with the aim to develop a model of independence mother in caring for preterm infants with an approach based Experiential Learning Theory of goal attainment. The approach used is cross sectional. This study examined the effects of maternal interaction between perceptions with preterm infants; mothers influence decisions in treating preterm infants against interaction, the effect of actions by the interaction. Analysis of the relationship was also conducted on the effect of interaction with the Experiential Learning and analyzes the influence of Experiential Learning with the independence of the mother in the care of preterm infants.

The second stage used quasi-experimental. The research objective in the second stage was to stage the simulation models. This study aimed to test the effectiveness of the application of the model-based approach to experiential learning theory of goal attainment in order to increase the independence of the mother in the care of preterm infants. Quasi-experimental research carried out with pretest and post-test before treatment after treatment was given. There was a quasi-experimental research experimental group and the control group, but the determination is not performed random sample. The populations in this research were all mothers who have preterm infants treated in perinatal dr. Wahidin Sudiro Husodo Mojokerto and hospitals Prof. dr. Soekandar Mojosari Mojokerto. The sample size in the treatment group and the control was 28 samples. Sampling technique used consecutive sampling. The instrument used in this study was a questionnaire, medical records and observation sheet or checklist. Exogenous variables, namely knowledge, decision, action was measured using a questionnaire. Other exogenous variables measured the interaction with the checklist. Meanwhile, to measure variables experiential learning used observation sheet (check list) based SOP preterm infant care. Endogenous variables namely the independence of mothers in caring for preterm infants was measured used observation sheet (check list). The validity of the test by looking at the value of convergent validity valid if it has a value of $>0.5$. If the composite reliability reliability test showed satisfactory value if $>0.6$. Research conducted at room perinatal dr. Wahidin Sudiro Husodo Mojokerto here in after referred to Hospital A and Hospital Prof. dr. Soekandar Mojosari Mojokerto hereinafter referred to Hospital B. The research was divided according the research phase, namely:

1. Phase 1 starts on August 2 until October $10^{\text {th }} 2014$

2. Phase 2 begins after the recommendation of the FGD was held on October $17^{\text {th }} 2014$. Phase 2 was conducted from November $2^{\text {th }}$ to December $12^{\text {th }} 2014$. 
Descriptive analysis techniques are to obtain a description of the characteristics of survey respondents from several aspects, including the mother's age, education, marriage age, marital status, age, pregnancy and the baby's weight. Descriptive analysis was also performed on variables knowledge, decision, action and reaction, interaction and independence of the mother in the care of preterm infants. Descriptive analysis was conducted by analysis of the frequency distribution of the measured variable. Subsequent analysis technique used in this study is the Partial Least Square (PLS). PLS is an alternative approach that shifts from the approach of Structural Equation Modeling (SEM) based covariance be based variant. PLS are more predictive models. In modeling the prediction purposes, PLS has consequences that testing can be done without a strong theoretical basis, ignoring some of the assumptions and parameters accuracy of predictive models, seen from the coefficient of determination. Analysis of the data in the second stage was a statistical test of independent t-test with a level of confidence $(\alpha)$ of 0.05 .

\section{RESULTS AND ANALYSIS}

A general description shows the characteristics of respondents as Table 1. Table 1 shows that the majority of the year most respondents aged between 20-35 years is 36 respondents and educated past high school as many as 49 respondents. All respondents had a marital status and long marriage married respondents are mostly 2-5 years as many as 44 respondents. While the data of respondents giving birth preterm infants with a gestational age of 34 weeks most of as many as 15 respondents and the majority of respondents gave birth weight preterm infants born between 2301-2400 grams as many as 23 respondents.

Table 1. Characteristics of Respondents

\begin{tabular}{|c|c|c|c|c|}
\hline \multirow{2}{*}{ No } & \multirow{2}{*}{ Characteristics } & \multirow{2}{*}{ Indicator } & \multicolumn{2}{|c|}{ Frequency } \\
\hline & & & $\sum$ & $\%$ \\
\hline \multirow[t]{3}{*}{1} & Age & $<20$ years & 15 & 27 \\
\hline & & $20-35$ years & 36 & 64 \\
\hline & & $>35$ years & 5 & 9 \\
\hline \multirow[t]{3}{*}{2} & Education & Elementary & 1 & 2 \\
\hline & & High School & 6 & 11 \\
\hline & & Senior high School & 49 & 87 \\
\hline 3 & Status Married & Married & 56 & 100 \\
\hline \multirow[t]{3}{*}{4} & Long Married & $\leq 1$ year & 1 & 2 \\
\hline & & $1-5$ year & 44 & 78 \\
\hline & & $>5$ year & 11 & 20 \\
\hline \multirow[t]{6}{*}{5} & Old Pregnancy & 32 week & 11 & 20 \\
\hline & & 33 week & 12 & 21 \\
\hline & & 34 week & 15 & 27 \\
\hline & & 35 week & 6 & 10 \\
\hline & & 36 week & 11 & 20 \\
\hline & & 37 week & 1 & 2 \\
\hline \multirow[t]{5}{*}{6} & Weight & $2000-2100$ gram & 8 & 14 \\
\hline & & $2101-2200$ gram & 10 & 18 \\
\hline & & $2201-2300$ gram & 7 & 11 \\
\hline & & $2301-2400$ gram & 23 & 41 \\
\hline & & 2401-2499 gram & 8 & 14 \\
\hline
\end{tabular}

Results of phase 1 with PLS analysis is to evaluate the structural equation model. PLS models more fully are as follows:

Illustrates the value is R-Square goodness-of-fit of the model. R-Square value recommended is greater than zero. Results of this study data processing using SmartPLS give R-square values as shown in Table 2. Table 2 shows the model of interaction and independence through Experiential Learning Care (ELC) is fit $(\mathrm{R}-$ Square $=0.544)$ greater than lenih interaction and independence $(\mathrm{R}-\mathrm{Square}=0.202)$.

Table 2. Goodness of Fit from R-Square

\begin{tabular}{lc}
\hline \multicolumn{1}{c}{ Variable } & R-Square \\
\hline Knowledge, Judgement, Action $\rightarrow$ Interaction & 0.838 \\
Interaction $\rightarrow$ Experiential Learning & 0.631 \\
Interaction $\rightarrow$ Independency & 0.202 \\
Interaction $\rightarrow$ Experiential Learning $\rightarrow$ Independency & 0.544 \\
\hline
\end{tabular}


Table 3 shows result of validity and reliability test on all latent variables are valid and reliable results, and the test sample $B=1000$ bootstrap yield significant results.

Table 3. Inner Test Weight On Independency Through Interaction and Experiential Learning With Bootstrap

\begin{tabular}{lcccc}
\hline \multicolumn{1}{c}{ Variable } & $\begin{array}{c}\text { Coefficient } \\
\text { Original }\end{array}$ & T Statistic & T table & Explanation \\
\hline Knowledge $\rightarrow$ Interaction & 0.161 & 2.427 & 1.96 & Significant \\
Judgement $\rightarrow$ Interaction & 0.684 & 10.617 & 1,96 & Significant \\
Action $\rightarrow$ Interaction & 0,157 & 2.110 & 1.96 & Significant \\
Interaction $\rightarrow$ experiential learning & 0.794 & 14.189 & 1.96 & Significant \\
Interaction $\rightarrow$ Independent & 0.202 & 2.713 & 1.96 & Significant \\
Experiential learning $\rightarrow$ Independency & 0.567 & 6.645 & 1.96 & Significant \\
\hline
\end{tabular}

Phase 2 trials conducted to assess the effectiveness of models. Phase 2 study results with the implementation of nursing used modules of Experiential Learning Care (ELC) in the treatment group and the control group leaflets media. Implementation in order to test models of Nursing in mothers of preterm infants with the approach of Experiential Learning Care (ELC) based Theory of Goal Attainment in order to be ready to care for the baby's own mother after discharge from the hospital. Treatment Experiential Learning Care (ELC) is given to the mother during 2 weeks is calculated from the first day of birth until the age of neonates (28 days). Observations independence was observed in mothers of preterm infants home after discharge from the hospital to the time of the visit no more than 28 days counted from birth. Model application independence in caring mothers of preterm infants through experiential approach based Learning Theory of Goal Attainment done with path analysis between mother knowledge about preterm infants (X1.1), the decision of the mother in the care of preterm infants (X1.2), acts mother (X1.3), interaction mother (X2), the implementation of experiential Learning Care (Y1) and the ability to self-reliance in caring mothers of preterm infants (Y2). Then obtained the following results as shown in Table 4.

Table 4. Test Results $\mathrm{t}$ test Independence Caring mother in Preterm Infants in the treatment group and control

\begin{tabular}{|c|c|c|c|c|c|c|c|c|}
\hline \multirow{3}{*}{ No } & \multirow{3}{*}{ Indicator } & \multicolumn{4}{|c|}{ group } & \multirow[b]{3}{*}{$\mathbf{t}$} & \multirow[b]{3}{*}{$p$} & \multirow{3}{*}{ Explanation } \\
\hline & & \multicolumn{2}{|c|}{ Mean \pm SD Treatmen } & \multicolumn{2}{|c|}{ Mean \pm SD Control } & & & \\
\hline & & Before & After & Before & After & & & \\
\hline 1 & $\begin{array}{l}\text { The ability to } \\
\text { know the signs } \\
\text { and symptoms of } \\
\text { apnea, } \\
\text { hypothermia, } \\
\text { impaired nutrition } \\
\text { and prevent } \\
\text { infection }\end{array}$ & $\begin{array}{r}77.49 \\
\pm 5.62\end{array}$ & $\begin{array}{l}86.67 \\
\pm 7.03\end{array}$ & $\begin{array}{c}72.00 \\
\pm 10.54\end{array}$ & $\begin{array}{c}72.50 \\
\pm 10.43\end{array}$ & 3.562 & 0.003 & Significant \\
\hline 2 & $\begin{array}{l}\text { Ability expected } \\
\text { problems that may } \\
\text { arise in preterm } \\
\text { infants }\end{array}$ & $\begin{array}{c}78.33 \\
\pm 8.04\end{array}$ & $\begin{array}{c}86.67 \\
\pm 10.54\end{array}$ & $\begin{array}{c}68.33 \\
\pm 13.49\end{array}$ & $\begin{array}{l}72.50 \\
\pm 6.85\end{array}$ & 3.562 & 0.003 & Significant \\
\hline 3 & $\begin{array}{l}\text { The ability to } \\
\text { demonstrate how } \\
\text { to handle a baby }\end{array}$ & $\begin{array}{c}73.00 \\
\pm 6.56\end{array}$ & $\begin{array}{l}78.33 \\
\pm 5.49\end{array}$ & $\begin{array}{c}65.67 \\
\pm 11.00\end{array}$ & $\begin{array}{l}69.33 \\
\pm 8.86\end{array}$ & 2.730 & 0.015 & Significant \\
\hline 4 & $\begin{array}{l}\text { The ability to take } \\
\text { decisions } \\
\text { involvement of } \\
\text { health workers }\end{array}$ & $\begin{array}{c}73.33 \\
\pm 8.60\end{array}$ & $\begin{array}{l}85.83 \\
\pm 9.66\end{array}$ & $\begin{array}{c}66.66 \\
\pm 13.61\end{array}$ & $\begin{array}{l}72.50 \\
\pm 6.85\end{array}$ & 2.623 & 0.017 & Significant \\
\hline
\end{tabular}

Table 4 gives information based on data on the independence of the mother in the care of preterm babies in the mother's ability to know the symptoms and signs of apnea problems, hypothermia, nutritional needs and the risk of infection showed an increase in self-sufficiency before and after Experiential Learning Care (ELC). The above data shows that the average increase in the independence of the mother prior to the ELC compared to independence after the ELC. Increased independence occurred in the treatment group. In the control group there was an increase, but the increase is not as high as had happened in keompok treatment. In the treatment group increase is very significant. This situation shows that the Experiential Learning Care (ELC) can increase the independence of the mother in the care of preterm infants. T-test results in the treatment group and the control group showed that there were significant differences in 
maternal autonomy in caring for babies in the treatment group before and after treatment. In the above table shows that on every indicator of independence in the treatment group there are significant differences. In the control group, the independence of each indicator there is no significant difference except the indicators of mother's ability to demonstrate how to care for preterm babies. Research hypothesis is accepted that there is a difference between the independence of the mother in caring for preterm infants using Experiential Learning Care (ELC) with conventional methods. Independence of the mother in the care of preterm infants using Experiential Learning Care (ELC) is increased compared with conventional methods.

Discussion of the results showed that the model of independence is strongly influenced by the interaction between the mother and the nurse further from the interaction of nursing intervention in the form of Experiential Learning Care (ELC). ELC is greater independence through the results rather than through direct interaction to independence. Increased involvement of the mother during nursing process in the hospital became the principal concern in using the approach Experiential Learning Care (ELC). ELC approach very effectively used to increase the independence of the mother in the care of preterm infants after discharge from the hospital.

The initial step achievement of roles as mothers (maternal role attainment) can be done from the beginning through the interaction of the mother and baby immediately after birth. The nurse is as soon as possible after 30 to 60 minutes after birth, involving the mother in caring for her baby. This is because time is a critical and sensitive period for the mother and baby to know each other and is bound together in a relationship of parenting [10]. Furthermore, the mother involved in the provision of measures to prevent apnea, hypothermia, impaired nutrition and prevents infection.

Experiential Learning Care (ELC) is done to emphasize that experience (experience) plays an important role in the learning process and distinguish it from other learning theories such as behaviorism or cognitive learning theory [11]. Stages of experiential learning: 1) Phase practice of concrete (Concrete Experience) 2) Phase Active and Reflective Experience (Reflection Observation). 3) Conceptualization Phase (Abstract Conceptualization). 4) Phase Experimentation Active (Active Experimentation).

Preterm infant care by involving mothers in every step of the process nursing mothers will be able to realize the importance of the role of mothers as primary caregivers who will continue after the return of the baby from the hospital. The learning process in the hospital is to raise awareness of the importance of the role of a mother and enough stock for the mother to be able to provide the best care for preterm babies.

Experience is everything that happens to us throughout our lives [12]. James Neil founded the experience refers to all the events that have been experienced by someone [13]. The opinion supports convey what John Dewey who stated that the experience is always an impact on the future of man, be good or bad. ELC learning process gives the mother an experience that is structured by using modules independence of mothers in caring for preterm infants. Learning activities begins with the introduction of maternal existence of a problem faced by preterm infants so that mothers can be aware of the existence of a baby. Furthermore, the mother is given the opportunity to learn the skills that nurses do. The mother is given the opportunity to think and solve problems at any time if the baby is having problems. And at the final stage mother asked to demonstrate the skills that have been mastered. This process accommodates the transformation of knowledge of nurses to the mother $\mathrm{d}$ a proses internalization cause high awareness in the mother. This is different from the learning process learning by Doing that only emphasizes the experience of trial and error. ELC learning experience provides meaning for someone to be able to take the essence of the experience itself for the best results in the baby that is to reduce the incidence of morbidity and mortality.

As a form of comparison, treatment with conventional learning model is dominated by the activities of nurses to provide instruction. This clearly would put the mother only as a passive recipient of information. Conventional models do not provide opportunities for women to understand further the importance of independence to care for their babies after discharge from the hospital. Independence of the mother in the care of preterm infants at home, indicated by the return of the baby's weight at birth as after a few days the weight loss due to evaporation or loss of water through the process of insensible water loss (IWL). The success of the independence of the mother is shown also by the absence of either infection in the eye or in the umbilicus [14].

The new finding in this research is the Experiential Learning Approach Care (ELC) more powerful in increasing the independence of mothers from the direct interaction to independence. Experiential Learning Care (ELC) is an operational form of transactions between a mother and a nurse. Transactions between the mother and the nurse were done so that the capital gain real experience in the care of her baby during ELC process takes place. ELC accommodate the exchange of information through learning by doing so inside the mother occurs internalization of information about skills in caring for the baby. The central role of the ELC is a learning process by using experience [11] Mother's experience will strengthen the transformation of knowledge that has been acquired and adequately applied in the treatment of preterm infants at home. Transformation and internalization obtained through Experiential Learning Care (ELC) will increase the 
independence of the mother. Independence of the mother in caring for preterm infants using nursing interventions in the form of Experiential Learning Care (ELC) more meaningful improvement when compared to the conventional models of intervention. ELC is a form of direct involvement of mothers during hospitalization. Involvement includes mother mother's presence directly when nurses provide care to infants, mothers observe and explain the action he had done the nurse, the mother demonstrated the skills acquired and can use these skills to make decisions and solve problems. The presence of mothers in the intervention process will trigger a thought process and raises awareness. Awareness will be reflected in the thought process and used as a foothold in the act and acquire new skills to be able to solve the problem. The involvement of the mother can begin immediately after the mother recovers from the time of delivery that can be started after 24 hours post partum until the return of preterm infants from the hospital.

\section{CONCLUSION}

Based on the results of research and discussion, it can be described conclusion that 1) Independence of the mother in caring for preterm infants using nursing interventions in the form of Experiential Learning Care (ELC) more meaningful improvement when compared to the conventional models of intervention. 2) Model ELC further streng then the independence of the nurse interaction with the mother in caring for preterm infants.

The application of the model Independence mother in caring for preterm infants using an approach Experiential Learning Care (ELC) based theory of goal attainment can be implemented more optimal with respect to: 1) Factors of nurses and midwives as good facilitators in a mother's active involvement in every element of Experiential Learning Care (ELC) so that mothers of preterm infants can independently take care of her baby after discharge from the hospital. Experiential Learning Care (ELC) will raise awareness of maternal and confidence to participate and be involved in the care of preterm infants so that knowledge, action and interaction of the preterm infant's mother will be able to rise. 2) Factors awareness of mothers as the main actors in the preterm infant care home needs to be further improved by assistance in caring for the baby, the mother is motivated to involve themselves actively in any action treatment in hospital so that the mother can implement home care skills. 3) Factors facilities and hospital policy by creating the conditions nurseries are accommodated through Clinical Practice Guidelines (CPG) and the comfort of the mother so Experiential Learning Care can be done well. 4) Factors other means to optimize the development of the means of learning by designing the room like at home so that the mother does not experience stress and improve their competence to serve as care providers on the baby.

Suggestions can be submitted researchers are 1) The process of nursing education should not be only in the form of activities to improve the quality of science, but must be followed by an increase in mental quality of caring. Thus the professional nurse will be generated and ready to meet the needs of the patient. 2) The next researcher can apply this model of self-reliance in other cases that require emergency treatment in addition to the preterm infant and mother empowerment.

\section{ACKNOWLEDGEMENTS}

The author would like to thank the Chairman of Bina Sehat Stikes PPNI Mojokerto who provided the opportunity to complete Doctoral Programe in University of Airlangga as well as to the Director Hospital dr. Wahidin Sudiro Husodo Mojokerto and Director Hospital Prof. Dr. Soekandar Mojokerto who have gave permission to this research.

\section{REFERENCES}

[1] March of Dimes Foundation, "Pregnancy, Babies, Prematurity", 2008. Retrieved from www.marchofdimes.com.

[2] Riskesdas, "Riset Kesehatan Dasar", Kementrian Kesehatan, Jakarta, Kemenkes RI, 2007.

[3] RSUD, "Profil RSUD Kota Mojokerto: Laporan rekam medik preterm,” Mojokerto, 2014.

[4] Hack, M.,Taylor, HG., Klein, N., Mercuri-Minich, N., "Functional limitations and special health care needs of 1014-year-old children weighing less than 750 grams at birth", Pediatrics, vol. 106, pp. 554-560, 2004.

[5] Miles, MS., Funk, SG, Kasper, MA., "The stress response of mothers and fathers of preterm infants", Research in Nursing and Health, vol. 15, pp. 261-269, 2012.

[6] Easterbrooks, MA., "Effects of infant risk status on the transition to parenthood", In GY. Michaels, WA. Goldberg (Eds.), "The transition to parenthood: Current theory and research", Cambridge, England: Cambridge University Press, pp. 176-208, 2008.

[7] Nadeau, L., Boivin, M., Tessier, R., Lefebvre, F, Robaey P., "Mediators of behavioral problems in 7-year-old children born after 24 to 28 weeks of gestation", Journal of Developmental and Behavioral Pediatrics, vol. 22, pp. $1-10,2004$.

[8] Fawcett, J., “But is it nursing research?”, Western Journal of Nursing Research, vol. 22, pp. 524-525, 2006. 
[9] Doni Mulyo Hadi, "Pengembangan Perangkat Pembelajaran menggunakan Model Experiential Learning pada standar Kompetensi membuat CD Player", Thesis not Publish, Surabaya, Universitas Negeri Surabaya, 2010.

[10] Danerek E., Dykes Ml., "Nutrition. Manual of neonatal care Ed-7”, Philadelphia: Lippincott William Wilkins, pp. 230-62, 2006.

[11] Kolb, AY., Kolb, DA., "Learning Styles and Learning Spaces: Enhancing Experiential Learning in Higher Education", Academy of Management Learning \& Education, vol. 4, pp. 193-212, 2005.

[12] Facione, P., Facione, N., "Thinking and Reasoning in Human Decision Making", The California Academic Press/ Insight Assessment, 2007.

[13] James Neill, J., "From alienation to familiarity: Experiences of mothers and fathers of preterm infants", Journal of Advanced Nursing, vol. 43, pp. 120-129, 2004.

[14] Deirdre E., Diane M1., "Nutrition. Manual of neonatal care Edisi ke-7”, Philadelphia: Lippincott William Wilkins, pp. 230-62, 2012.

\section{BIOGRAPHIES OF AUTHORS}

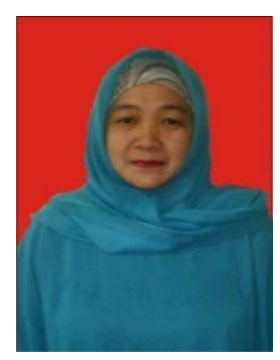

Noer Saudah was born on 15 September 1971 in Mojokerto. She studied in Bachelor of Nursing, Faculty of Medicine Airlangga University on 2002. She completed my master in medicine faculty Airlangga University on 2008. This year, she finished doctoral postgraduate programme pulict health Airlangga University. Seh has many interests in maternity of nursing and reproduction of health. She is a lectur on STIKes Bina Sehat PPNI Kabupaten Mojokerto

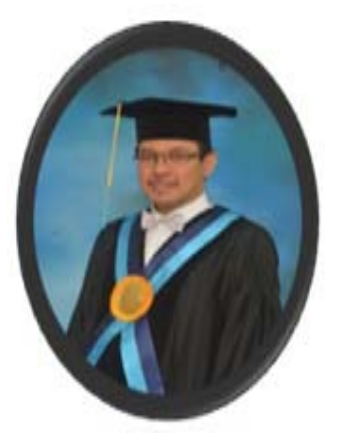

Prof. Dr. Nursalam, M.Nurs (Hons) is a Professor in Nursing, Airlangga University and he is a my promotor in doctoral programme. He was born on 25 Desember 1966 in Kediri. He was studied in Med. Surgical Nursing, Lambton College, Sarnia Ontario Canada, on 1991. He completed Master of Nursing (Coursework), Univ. Wollongong, NSW, Australia on 1996. He continued Honours Master of Nursing, University of Wollongong, New South Wales, Australia, on 1997 and he complete Doctor, Model of Nursing Care for HIV-AIDS, Postgraduate Programme Airlangga University on 2005. This year, He is a dean on faculty of nursing Airlangga University. And He is a head PPNI east Java 2015-2020.

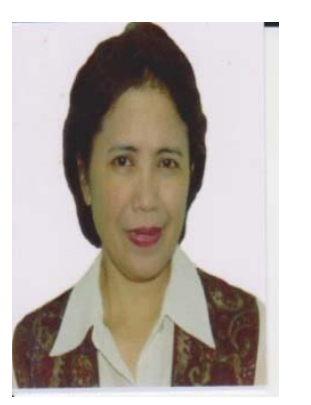

Dr. Merryana Adriani, S.KM., M.Kes. is a Lecturer in Public Health, Airlangga University. She was studied Doctor Postgraduate Programme Airlangga University on 2009. Before she studied Master of Nutritional Public Health Airlangga University on 2000. She is Head of Division Academic, Faculty of Public Health Airlangga University (2011- now)

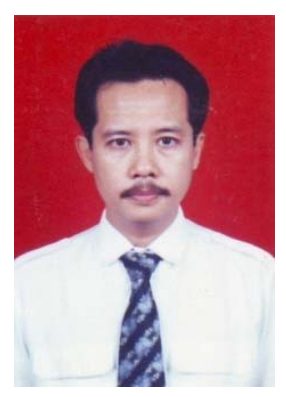

Dr. dr. Agus Sulistyono, SpOG (K) studied Doctor Postgraduate Programme Airlangga University on 2011. Before he studied Specialist of Obstetri and Gynecologic, medicine faculty Airlangga University on1998. He finished Medical of faculty Airlangga University on 1987. Now, he is Lecturer in Faculty of Medical Airlangga University (since 1999-now), Consultan of Feto-Maternal, Collegium Obstetric and Ginekology Indonesia (2003-now) and Medicine on RSUD Dr. Soetomo Surabaya 